DOI 10.31558/2519-2949.2019.2.3

УДК $340.116: 316.42$

ORCID ID: https://orcid.org/0000-0001-7283-3528

Польовий М. А., Донецький національний університет імені Василя Стуса

\title{
ПРОБЛЕМИ РЕАЛІЗАЦІЇ ПРАВА НА ОСВІТУ ДІТЕЙ, ЩО ПОТЕРПАЮТЬ ВІД ЗБРОЙНИХ КОНФЛІКТІВ
}

\begin{abstract}
Статтю присвячено аналізу нагальних проблем реалізації права на освіту дітей, щуо потерпають від збройних конфліктів.

Основним матеріалом для висловлюваних положень та висновків статті стали кейси, пов'язані із російсько-украӥнським збройним конфліктом на сході Украӥни та фактичною російською окупацією частин Луганської та Донецької областей.
\end{abstract}

Відзначено, щуо слід виокремлювати різні групи дітей серед тих, щуо потерпають від конфліктів та окупації. В тому числі тих, що живуть у окупованій зоні, тих, які живуть у “сірій” зоні, та тих, щуо виїхали далеко від зони конфлікту і проживають у інших областях Украӥни.

Визначено, щзо до основних проблем, які пов'язані із реалізацією права на освіту дітей, щяо перебувають у зоні збройних конфліктів, можна віднести такі, як інтеграчія дітей-ВПО до нового освітнього простору, в якому вони опинились поза своєї волі; в разі проживання на окупованій території - навчання в закладах середньої та вищої освіти лише за навчальним програмами, які визначає окупаційна адміністрачія; низка проблем, пов'язана із вступом на навчання до українських вишів; об 'єктивно недостатні можливості для агітаџї на продовження навчання після середньої школи в ОРДЛО саме у вишах Украӥни; визначення майбутнього життєвого шляху ВПО та вихідиів з ОРДЛО після закінчення вищої освіти в Україні. В статті зазначається, що серед названих проблем державні органи та громадські організаиії найбільще опікуються інтеграчією дітей-ВПО до нового освітнього простору та забезпеченням можливостей вступу абітурієнтів до украӥнських вишів. Зазначено також як об'єктивні, так і суб 'єктивні перепони на шляху до досягнення цілей, постульованих у відношенні до реалізаиії права на освіту дітей, які потерпають від російськоукраӥнського конфлікту.

Ключові слова: право на освіту, права дітей; наслідки збройних конфліктів.

Сучасний світ має багато проблем, які пов'язані із старими та новими конфліктами, старими та новими засобами їх вирішення. Але незалежно від того, які саме джерела мають сучасні конфлікти і того, наскільки сучасними засобами вони викликані чи підтримуються, завжди залишаються фундаментальні проблеми, що пов'язані із мирним населенням, яке потерпає від конфліктів у першу чергу. Однією з таких проблем є проблема дотримання прав дітей. В тому числі права на освіту. Навіть за умов переміщення дітей із зон конфлікту чи окупації та набуття ними статусу внутрішньо переміщених осіб залишаються додаткові проблеми щодо забезпечення таким дітям права на отримання освіти на рівні із рештою населення країни. Забезпечення реалізації прав внутрішньо переміщених осіб на отримання освіти $є$ вкрай важливим для розвитку дітей, підлітків, молоді та їх можливостей у майбутньому. Однакові умови доступу до освіти є важливим показником інтеграції внутрішньо переміщених осіб у приймаючі територіальні громади.

Отже, завданням даної статті є аналіз нагальних проблем реалізації права на освіту дітей, що потерпають від збройних конфліктів.

Основним матеріалом для висловлюваних положень та висновків статті стали кейси, пов'язані із російсько-українським збройним конфліктом на сході України та фактичною російською окупацією частин Луганської та Донецької областей.

На нашу думку, слід виокремлювати різні групи дітей серед тих, що потерпають від конфліктів та окупації. Серед них можна виділити:

- дітей, що живуть у окупованій зоні;

- дітей, які живуть у “сірій” зоні;

- дітей, що виїхали далеко від зони конфлікту і проживають у інших областях України. 
Серед останніх двох категорій слід також виділяти групи дітей, які отримали (як правило, разом із батьками) статус внутрішньо переміщених осіб та тих, що його не отримали.

Крім того, із дещо різними проблемами стикаються діти шкільного віку, та ті діти, які отримали повну середню освіту та мають здійснити свій вибір щодо продовження навчання у закладах вищої освіти.

Отже, спробуємо узагальнити основні проблеми, які виникають у зв'язку із реалізацією права дітей, що потерпають від збройних конфліктів.

Окрему складну проблему, на яку, щоправда, найбільше звертають уваги державні органи та громадські організації, складає проблема інтеграції дітей-ВПО до нового освітнього середовища. Ця проблема $\epsilon$ частиною більш загального завдання інтеграції ВПО будь-якого віку до нових для них громад. Зазвичай звертається увага на певну стигматизацію як дорослих ВПО у соціальному середовищі, так і дітей у дитячих колективах - мовляв, “через вас почалась війна, ви принесли руський мир" тощо. На жаль, в пресі кількох останніх років та в соціальних мережах неодноразово звертали увагу на спорадичні прояви подібного відношення до вимушених переселенців зі сходу України. Зрозуміло, що носіями такого відношення виступають в першу чергу дорослі, але оскільки діти найчастіше копіюють соціальне ставлення батьків, в шкільних колективах прояви негативного відношення дітей до однокласників-ВПО також фіксувалися. Показовими $є$ кейси, що фіксуються на межі із сірою зоною, де також проживають ВПО,- щонайменше в деяких школах вчителі не роблять різниці між місцевими дітьми, та дітьми переселенців-ВПО. Власне, вони не роблять відомою інформацію про те, хто з дітей є ВПО. В результаті немає грунту для потенційних негараздів між дітьми. Можна всіляко вітати подібну практику. Водночас виникає досить складна проблема: з одного боку є позитивом, коли діти ВПО “розчиняються" у новому середовищі без фіксації свого статусу. 3 іншого - внаслідок певних, інколи недолугих, інколи недостатніх, але все ж таки існуючих кроків держави щодо підтримки ВПО подібна утаємниченість статусу дітей-ВПО не може довго зберігатись. Тому більш продуктивним представляється не втаємничення, а навпаки, спокійна публічна фіксація статусу дітей ВПО із демонстрацією рівного відношення до них з боку вчителів та, можливо, певна роз'яснювальна робота вчителів із батьками місцевих дітей. Гіпотетично можна уявити підтримку втаємничення статусів дітей-ВПО, але ефективно це можливе лише за умов припинення всілякого піклування держави про ВПО. Чи варто намагатись зберігати шило (відомості про статус ВПО) в мішку? На нашу думку- ні. Більш продуктивним представляється здійснення спеціальних заходів із інтеграції ВПО до місцевої громади. Причому перспективними та корисними варіантами проведення таких заходів $€$ формат родинних посиденьок або ж родинних вікендів, родинних фестивалів тощо - тоді у інтеграційний формат залучаються цілі родини як ВПО, так і приймаючої громади. Крім того, важливим є створення центрів сімейного дозвілля, в першу чергу, в місцевостях із значною кількістю ВПО. 3 цієї точки зору цікавим видається досвід проекту «Карітас Польща», в межах якого здійснюються різноманітні заходи із підтримки мігрантів в цю країну [1]. Крім інших, цікавою представляється програма своєрідного менторства над підлітками під назвою «Старший брат, старша сестра».

Діти, що проживають в сірій зоні, стикаються із додатковою проблемою забезпечення безпеки життя у зв'язку із наближеністю лінії зіткнення та відповідною підвищеною небезпекою збройного ураження.

Діти, що проживають на окупованій території, фактично позбавлені можливості отримувати освіту за освітніми програмами української середньої школи. Оскільки переміщення через лінію розмежування досить складне, та, крім того, суміщається із додатковим ризиком для життя, то немає можливості регулярних перевезень дітей з окупованих територій для навчання в закладах середньої освіти на території “материковоі” України. Отже, діти шкільного віку, які в силу різних обставин залишились на окупованій території, якщо й отримують середню освіту, то лише на тій самій території за програмами, затверджуваними та контрольованими окупаційною владою.

Ціла низка проблем щодо реалізації права дітей на освіту пов'язана із забезпеченням можливостей отримання вищої освіти на території, підконтрольній Україні.

Окрему групу проблем створюють процедури складання ЗНО по закінченні середньої школи. Дійсно, українська влада надає можливість дітям з окупованих територій реєструватись та приїздити складати ЗНО на території, підконтрольній Україні, але на цьому шляху виникають кілька організаційних бар'єрів: по-перше, дати складання ЗНО для дітей з окупованих територій $\epsilon$ загальновідомими (що очевидно та, на перший погляд, виглядає розумним), внаслідок чого окупаційна влада має можливості ускладнити чи взагалі перекрити можливості виїзду дітей для 
складання ЗНО у відповідні дні. Практика минулих років показує, що саме так і відбувається. Особливо активно влада непідконтрольних територій робила це в 2017 році [2]. В результаті діти з окупованих територій не мають можливості потрапити вчасно до пунктів проведення ЗНО та автоматично позбавляються можливості брати участь у конкурсі до українських вишів. Частковим кроком до вирішення цієї проблеми могло б стати запровадження певного виключення із системи “одного дня" для ЗНО, яка діє в Україні. Наприклад, якщо дітям 3 окупованих районів дозволити складати ЗНО в будь-який день протягом, скажімо, трьох тижнів, то владі на окупованих територіях буде складніше заважати бажаючим скласти ЗНО в “материковій" Україні, бо в них буде можливість виїхати в будь-який зручний день протягом цього інтервалу та скласти бажані тести ЗНО. Крім того, зважаючи на часові витрати, необхідні для перетинання лінії розмежування, вкрай корисним представляється запровадження в містах, де створені можливості для складання ЗНО жителями з окупованих територій, певні місця перебування на зразок хостелів для двох-трьох денного перебування учнів та їх батьків на час складання ЗНО.

Слід констатувати, що на даний час українська влада пішла шляхом запровадження спеціальних освітніх центрів «Донбас-Україна» та «Крим-Україна», через які абітурієнти з непідконтрольних територій мають можливість вступати до вишів України без ЗНО та навіть без атестату про середню освіту. Наразі існує 37 центрів «Донбас-Крим» та 41 центр «ДонбасУкраїна» [3]. 3 цих 41 центра 17 створено на базі переміщених вишів та коледжів, а ще 24 - на базі «стаціонарних» вишів, як правило, центральної та південної України. Щоправда, статистика вступу через ці центри надає лише скромні підстави для оптимізму: наприклад, в 2018 році за консультаціями до цих центрів звернулись близько 4000 осіб (тобто в середньому 50 осіб до кожного центру). Але вступили через ці центри за спрощеною процедурою в тому ж таки 2018 році - лише 1522 особи за програмою «Донбас-Україна» та 227 осіб за програмою «КримУкраїна» [4]. У 2017 році через згадувані освітні центри вступили до вишів України за спрощеною процедурою загалом 1550 абітурієнтів із ОРДЛО [4]. Дійсно, можна радіти 3 того, що динаміка вступу абітурієнтів з тимчасово окупованих територій позитивна, але якщо згадати, що, наприклад, у 2017 році випускників шкіл на території ОРДЛО було близько 55 тис [2], виявляється, що до українських вишів за спрощеною схемою через освітні центри вступив лише кожен 35-й випускник шкіл з території ОРДЛО. Відповідно приблизно так само і в 2018 році можливостями вступу через освітні центри скористався лише кожен 33-35-й випускник 3 тимчасово окупованих територій.

Подібний стан речей актуалізує наступну проблему: не просто проблему надання змоги вчорашнім школярам вступати до українських вишів, а проблему вибору ними саме українських вишів для навчання.

На нашу думку, в першу чергу важливу роль відіграють міркування організаційного плану: наважившись відправити дитину в будь-яке інше місце для навчання батьки розуміють необхідність існування надійного каналу зв'язку із дитиною - можливості періодичного відвідування дитиною дому чи, навпаки, iї відвідування батьками. Оскільки студенти перших курсів, як правило не можуть похвастатись фінансовою самостійністю, виникає й питання банальної передачі грошей батьками. За умов їх проживання на території ОРДЛО регулярна підтримка подібних зв'язків стає вкрай ускладненою. Відповідно, проблема інституційної та організаційної можливості вступу абітурієнтів з ОРДЛО до українських вишів заступається іншою - проблемою фактичного, несприятливого для перетинання, кордону та, певною мірою, кордону у свідомості.

Крім того, не можна виключати й впливу ідеологічної антиукраїнської «обробки» учнів під час їх навчання у школі, а також їх батьків, які, кінець-кінцем, найчастіше приймають рішення щодо подальшого шляху для навчання своїх дітей.

Отже, можна радіти із того, що хоча б кожен 35-й випускник із шкіл на території ОРДЛО вступає до українських вишів.

Насамкінець, які є альтернативи для потенційних абітурієнтів з окупованих територій? Як відомо, невдовзі по окупації були створені на окупованих територіях та продовжують існувати клони тих вишів, які працювали в Донецькій та Луганській областях до початку війни. Вони працюють в тих самих приміщеннях, та мають переважно такі самі назви, які мали їх попередники, що були переміщені на неокуповану територію. Так, їх дипломи не визнаються, здебільшого, жодною країно в світі (навіть Російською Федерацією: в цьому є, судячи з преси ОРДЛО, певні виключення для окремих спеціальностей [5], але вони не змінюють загальної картини). Але ж ці 
виші «під боком» в батьків, що знімає названі вище організаційні проблеми. На жаль, можна констатувати, що суто агітаційні заходи із навчання в Україні, включно із завішуванням усіх пропускних пунктів листівками щодо здобуття української освіти [4], мають певну межу ефективності, якої вони, скоріше за все, вже досягли. Подальшого збільшення притоку абітурієнтів 3 тимчасово окупованих територій можна очікувати, на нашу думку, лише за кардинальної зміни умов перетину лінії розділення, що, в силу різних причин, не представляється реалістичним найближчим часом.

Відповідно, доводиться констатувати, що більшість дітей, які закінчують школи на тимчасово окупованих територіях, позбавлені можливості повноцінної реалізації права на отримання вищої освіти.

Втім, на цьому проблеми для дітей, які потерпають від збройних конфліктів та окупації, не закінчуються. Наступна проблема лише починає формуватись, але дедалі більше вона буде набувати гостроти: це проблема визначення подальшого життєвого шляху тих сміливців та патріотів 3 окупованих територій, які спроміглись вступити на навчання у виші в Україні (нехай i за спрощеною процедурою за лінією освітніх центрів) та успішно закінчили його. Який шлях може обрати та обере молода людина 22-23 років, сім'я якої вірогідно, проживає в ОРДЛО, і яка отримала вищу освіту в Україні? Крім звичайного непростого вибору шляху працевлаштування після вишу такій людині треба ще вирішувати непросту моральну дилему: повертатись до сім'ї на окуповані території (i, до речі, нести із собою надбані знання - чи входило це у плани української держави? це окреме складне питання) або ж шукати кращої долі в неокупованій Україні чи в світі. Вочевидь, якщо не створити бодай нормальні умови існування таким людям на етапі студентського життя, Україна як держава обов'язково програє боротьбу за них - бо вони будуть вимушені шукати кращої долі або за західним кордоном, або за східною лінією розмежування. Водночас аналіз цієї проблеми виходить за межі даної статті.

Отже, матеріал, пов'язаний із тимчасово окупованими територіями Сходу України та ВПО, дає можливість визначити, що до основних проблем, які пов'язані із реалізацією права на освіту дітей, що перебувають у зоні збройних конфліктів, можна віднести наступні:

1) інтеграція дітей-ВПО до нового освітнього простору, в якому вони опинились поза своєї волі; 2) в разі проживання на окупованій території - навчання в закладах середньої та вищої освіти лише за навчальним програмами, які визначає окупаційна адміністрація; 3) низка проблем, пов'язана із вступом на навчання до українських вишів; 4) агітація на продовження навчання після середньої школи в ОРДЛО саме у вишах України; 5) визначення майбутнього життєвого шляху ВПО та вихідців з ОРДЛО після закінчення вищої освіти в Україні.

1. Caritas Polska. https://caritas.pl/

\section{Бібліографічний список:}

2. Абитуриент с неподконтрольной территории: Чего ждать в 2018 году? Донецкие новости. 04.01.18. https://dnews.dn.ua/news/662243

3. Освітні центри. Офіційний сайт Міністерство освіти і науки України. https://mon.gov.ua/ua/zhitelyamdonbasu-ta-krimu/studentam/osvitni-centri

4. У 2018 році до українських ВНЗ через освітні центри вступило 1749 студентів з тимчасово окупованих територій Донецької, Луганської областей та АР Крим. Міністерство з питань тимчасово окупованих територій та внутрішньопереміщених осіб. 24.10.2018. https://mtot.gov.ua/u-2018-rotsi-do-ukrayinskyh-vnzvstupylo-1749-studentiv-z-tymchasovo-okupovanyh-terytorij-donetskoyi-luganskoyi-oblastej-ta-ar-krym

5. Вузы ДНР начали выдавать выпускникам российские дипломы. Информационное агентство «Исток». Июнь 29, 2019. http://miaistok.su/vuzy-dnr-nachali-vydavat-vypusknikam-rossijskie-diplomy

1. Caritas Polska. https://caritas.pl/

\section{References:}

2. Abyturyent s nepodkontrol'noy terrytoryy: Cheho zhdat' v 2018 hodu? Donetskye novosty. 04.01.18. https://dnews.dn.ua/news/662243

3. Osvitni tsentry. Ofitsiynyy sayt Ministerstvo osvity i nauky Ukrayiny. https://mon.gov.ua/ua/zhitelyamdonbasu-ta-krimu/studentam/osvitni-centri

4. U 2018 rotsi do ukrayins'kykh VNZ cherez osvitni tsentry vstupylo 1749 studentiv z tymchasovo okupovanykh terytoriy Donets'koyi, Luhans'koyi oblastey ta AR Krym. Ministerstvo z pytan' tymchasovo okupovanykh terytoriy ta vnutrishn'operemishchenykh osib. 24.10.2018. https://mtot.gov.ua/u-2018-rotsi-do-ukrayinskyh-vnz-vstupylo-1749studentiv-z-tymchasovo-okupovanyh-terytorij-donetskoyi-luganskoyi-oblastej-ta-ar-krym

5. Vuzy DNR nachaly vydavat' vypusknykam rossyyskye dyplomy. Ynformatsyonnoe ahent·stvo «Ystok». Yyun' 29, 2019. http://miaistok.su/vuzy-dnr-nachali-vydavat-vypusknikam-rossijskie-diplomy 


\section{Polovyi M. A. Problems of realization the right to education of children suffering from armed conflicts}

The article is devoted to the analysis of urgent problems of realization of the right to education of children suffering from armed conflicts. Cases related to the Russian-Ukrainian armed conflict in eastern Ukraine and the actual Russian occupation of parts of Lugansk and Donetsk regions were the main material for the stated provisions and conclusions of the article.

It was noted that different groups of children should be parcel out among those affected by conflict and occupation. Including those who live in the occupied zone, those who live in the "gray" zone and those who have left far from the conflict zone and reside in other areas of Ukraine.

It is determined that the main problems related to the realization of the right to education of children in the conflict zone are related to the integration of IDP children into the new educational space in which they were left out of their own free will; in the case of residence in the occupied territory, training in secondary and higher education institutions only according to the educational programs defined by the occupation administration; a number of problems related to enrollment in Ukrainian universities; objectively insufficient opportunities for agitation for continuing education after high school in Particular Areas of Donetsk and Lugansk Regions in the universities of Ukraine; determining the future life path of IDPs after graduating from higher education in Ukraine. The article states that among the mentioned problems, the state authorities and civil organizations are most concerned with the integration of IDP children into the new educational space and providing opportunities for entry of entrants to Ukrainian higher education institutions. Both objective and subjective obstacles to the achievement of the goals postulated in relation to the right to education of children suffering from the Russian-Ukrainian conflict are outlined.

Key words: right to education, children's rights; consequences of armed conflicts. 